\title{
Ethnic and Religious Prejudices in the Turkish Social Landscape
}

\section{Zeki Sarigil*}

\author{
Department of Political Science, Bilkent University, Ankara, Turkey \\ *Corresponding author. Email: sarigil@bilkent.edu.tr
}

Submitted December 2017; revised June 2018; accepted August 2018

\begin{abstract}
Focusing on the dominant group's (Sunni-Turks) attitudes towards the largest ethnic and religious minorities (Kurds and Alevis, respectively) in the Turkish social landscape, this study investigates the determining factors of ethnic and religious prejudices in intergroup relations. The study draws several hypotheses about out-group rejection from social identity and ethnic competition theories and tests them utilizing new, original public opinion survey data. The empirical findings confirm the presence of a substantial degree of ethnic and religious prejudices in the Turkish social setting. Furthermore, statistical analyses show that unlike economic factors, political and cultural variables, such as ideological orientations, nationalist tendencies, and religiosity, perform much better in terms of predicting Sunni-Turks' exclusionary attitudes towards ethnic and religious out-group members. Thus, intergroup prejudice or intolerance in the Turkish setting is deeply ingrained in cultural and political divisions rather than in economic factors. The study also discusses some major theoretical and practical implications of the empirical findings.
\end{abstract}

\section{Introduction}

This study investigates the determining factors of ethnic and religious prejudices in the context of intergroup relations. Ethnic and religious prejudices usually include negative or antagonistic attitudes towards out-group members. In Allport's (1979: p. 7) words, prejudice is 'an avertive or hostile attitude toward a person who belongs to a group, simply because he belongs to that group, and is therefore presumed to have the objectionable qualities ascribed to the group'. The author further notes that prejudicial attitudes involve 'feelings of scorn or dislike, of fear and aversion, as well as various forms of antipathetic conduct: such as talking against people, discrimination against them, or attacking them with violence' (Allport, 1979: p. 7). Similarly, Brown (1995: p. 8) defines prejudice as 'the holding of derogatory social attitudes or cognitive beliefs, the expression of negative affect, or the display of hostile or discriminatory behaviour towards members of a group on account of their membership of that group'. As these conceptualizations suggest, prejudicial beliefs and attitudes have major consequences for intergroup relations and interactions. Such attitudes often lead to social exclusion, inequality, and discrimination and so promote intergroup tensions, hostilities, and conflicts. As these processes eventually undermine social peace and harmony, a better understanding of the determinants of prejudicial and exclusionary beliefs and attitudes is vital in terms of containing or reducing intergroup tensions and conflicts in social and political domains.

With such motivations, this study focuses on intergroup attitudes and relations in the Turkish social landscape and empirically examines the attitude of members 
of the dominant group (i.e. a Sunni-Turkish majority) towards the largest ethnic and religious minorities (i.e. Kurds and Alevis, respectively). Sunni-Turks constitute the ethnic and religious mainstream or dominant group in almost all spheres of social and political life in the Turkish setting. That said, the Turkish social landscape has a highly heterogeneous structure, with several ethnic and religious divisions and cleavages (e.g. Turks vs. Kurds; Alevis vs. Sunnis). Hence, the Turkish case provides an ideal socio-political context in which to examine the mechanisms of social closure and of out-group prejudice. Theoretically speaking, this study enhances our comprehension of the determinants of social closure and prejudice in general. Empirically, by conducting a systematic comparison of the dominant group's attitudes towards suppressed or disadvantaged ethnic and religious minority out-groups in Turkey, this study contributes to our knowledge of intergroup relations and tensions in the Turkish social setting. Furthermore, examining social closure and out-group prejudice in Turkey, a Muslim-majority context, would also shed light into ethnic and religious prejudices in other Muslim societies, which have been plagued with several sectarian and ethnic divisions and cleavages.

Thus, focusing on ethnic and religious exclusionism in the Turkish social context, this study explores the following questions: How do the members of the dominant group (Sunni-Turks) view Kurdish and Alevi minority out-groups? Is there any difference in the dominant group's social distance from ethnic and from religious minorities? For instance, is the religious prejudice of Sunni-Turks stronger or is their ethnic prejudice stronger? What factors might account for the variance in the majority group's intolerance and prejudice towards religious and ethnic minorities? What can we learn from this particular case (i.e. Sunni-Turkish majority's social closure vis-à-vis major ethnic and religious minority groups) about the factors that might shape intergroup prejudice in general?

To answer such questions, this study utilizes new data derived from a public opinion survey conducted in 2015 with a nationally representative sample. Empirical analyses show that in the private realm, Sunni-Turks are socially more distant towards ethnic and religious minority groups than in the public domain, which implies that both ethnic and religious social boundaries appear to be relatively brighter, thicker, and so less porous or permeable in the private sphere. A more striking finding is that across Kurdish and Alevi out-groups, SunniTurks have a higher degree of social distance from Kurds in the public sphere but from Alevis in the private sphere. In other words, in the private sphere, religious prejudice is relatively stronger, while ethnic prejudice is stronger in the public realm. Furthermore, the empirical findings indicate that compared to economic variables, cultural and political variables and factors such as ideological orientations (i.e. a left-right division), religiosity, and nationalist tendencies perform much better in terms of predicting Sunni-Turks' exclusionary and antagonistic attitudes towards ethnic and religious out-groups. These findings suggest that prejudicial and exclusionary attitudes in the Turkish social setting appear to be deeply rooted in cultural and political conditions and divisions rather than in economic factors.

The rest of the article proceeds as follows: the theoretical section (next) utilizes social identity and ethnic competition theories and advances some propositions about the possible impact of ideology, religiosity, and nationalism on the dominant majority group's social distance from major ethnic and religious minority out-groups in the Turkish social landscape. This section is followed by the research design, which introduces the data, key variables, and measurement. The empirical results section presents both descriptive and multivariate analyses and findings, and the final section discusses the theoretical and practical implications of the findings.

\section{Theoretical Perspectives}

This study analyses the majority group's social distance and prejudice in Turkey towards the country's largest ethnic and religious minority groups through the lenses of two major theoretical perspectives: social identity theory (SIT) ${ }^{1}$ and ethnic competition theory (ECT).

Briefly stated, SIT, which focuses on the role of self-conception in group membership and in intra- and intergroup processes and interactions (Hogg, 2006), suggests that in the context of intergroup relations, in-group members have a tendency to differentiate themselves by augmenting similarities within the in-group and differences from out-groups (accentuation principle). Another key proposition of SIT is that in intergroup settings, group members desire favourable self-esteem, selfenhancement, and a favourable self-concept. Hence, ingroup members try to achieve and maintain a positive social identity by evaluating in-group members much more positively or favourably than out-group members (also known as in-group bias, in-group positivity, or in-group favouritism) (see Tajfel, 1981, 1982; Brewer, 1986, 2001; Tajfel and Turner, 1986; Hewstone, Rubin and Willis, 2002; Hogg, 2006). One way of maintaining a positive social identity is identified as ethnocentrism. For Sumner (2002: p. 13), this notion refers to the belief that 'one's own group is the centre of everything, and all 
others are scaled and rated with reference to it .... Each group nourishes its own pride and vanity, boasts itself superior, exalts its own divinities, and looks with contempt on outsiders'.

As a complementary approach to SIT, ECT expects that processes of competition among ethnic groups for the same economic resources are likely to increase the salience of ethnic boundaries and so trigger ethnic mobilization, tensions, and conflicts. For instance Olzak contends that

when competitive forces among ethnics are released, ethnic boundaries become highly salient during periods of intense competition over resources ... [E]thnic competition intensifies ethnic boundaries when two or more ethnic populations try to acquire the same valued resources, such as jobs, housing, or marriage partners ... [C]ompetition processes spark ethnic conflict [and] do so when ethnic groups attempt to occupy the same resource environment and compete for the same limited set of resources (emphasis in original). (1992: p. 28; see also Okamoto, 2003)

The ECT approach tends to limit ethnic competition to economic or material resources such as jobs, security, wealth, and/or power. However, ethnic groups might also compete over relatively more ideational or symbolic values, such as prestige, status, and/or legitimacy (see Schneider, 2008). In the case of competition between an advantaged ethnic majority and a disadvantaged ethnic minority, clashes over material and/or symbolic resources and values are likely to escalate threat perceptions among the members of the ethnic majority. For instance, members of the advantaged ethnic majority would view improvements in the ethnic minority's social, economic, or political status as a threat to their dominant position (Olzak, 1992: p. 42). Heightened threat perceptions are likely to induce negative or antagonistic attitudes towards the members of the ethnic minority, decreasing interethnic trust and tolerance (see Brewer, 2001; Hewstone, Rubin and Willis, 2002; Scheepers, Gijsberts and Coenders, 2002; Savelkoul et al., 2011). Interethnic prejudice, intolerance, and hostility, in return, reinforce social closure and exclusion among ethnic groups and so strengthen ethnic boundaries.

\section{Hypotheses}

This study is particularly interested in the impact of ideology, religiosity and nationalism as the most relevant factors shaping the Sunni-Turkish majority's exclusionary and prejudicial attitudes towards ethnic and religious minority out-groups in Turkey. Utilizing the
SIT and ECT theories presented briefly above, this section constructs hypothetical expectations about the impact of ideology, religiosity, and nationalism on ethnic and religious exclusionisms and prejudices.

Ideology: One might expect Sunni-Turks' ideological orientations to shape their attitudes towards Kurdish and Alevi out-groups simply because Kurdish and Alevi movements in Turkey both have leftist roots and orientations. Historically speaking, during the extreme ideological polarization and political violence between the ultranationalist right and the socialist left in Turkey in the 1970s, the majority of Alevi and Kurdish social and political groups sided with the socialist camp. Beyond such historical legacies and memories, the majority of Kurdish voters have been voting for leftist, pro-Kurdish political parties in the last four general elections (June 2011, June 2015, November 2015, and June 2018). Regarding Alevis, empirical analyses confirm that they have also been more likely to vote for left-oriented, secular political parties (see Çarkoğlu, 2005). Thus, given that these minority groups have been associated with leftist movements and ideologies, one might expect to see a greater degree of Othering directed towards them from right-oriented members of the Sunni-Turkish majority. For instance, although openly socialist or communist political movements and formations in contemporary Turkish society and politics remain rather marginal and such political parties fail to receive substantial Kurdish and Alevi support, Kurds and Alevis are still occasionally viewed and referred to as 'Communists' in rightist political discourses (see also Çelik, Bilali and Iqbal, 2017). Such statements can also be interpreted as one of the consequences of the legacy of ideological polarization, enmity, and violence from the 1960s and 1970s. In brief, one might hypothesize that:

H1: Right-oriented Sunni-Turks should be socially more distant to both Kurds and Alevis.

Religiosity: Like ethnicity and nationalism, religion is 'a mode of identification, a mode of social organization and a way of framing political claims' (Brubaker, 2012: p. 4). Hence, as a basic source and form of social and cultural identification, religion is an important resource not only for individual and collective meaning making but also for social closure and boundary-making processes (Brubaker, 2012; Dahinden and Zittoun, 2013). As Brubaker (2012: p. 4) further notes, similar to ethnicity and nationalism, religion is a way of 'identifying oneself and others, of construing sameness and difference and of situating and placing oneself in relation to others'. 
In terms of the role of religion in social closure processes at the individual level, one might expect that among relatively more-religious individuals, religious loyalties and attachments would be more salient in selfidentification practices (see also Trittler, 2017). As these feelings might generate a favourable attitude towards religious in-group members, they would likely increase social distance from members of a religious out-group. In other words, a strong degree of religiosity is likely to generate thicker social boundaries between in-group members and outsiders, constituting a major barrier towards intergroup relationships. For instance, in their analysis of the role of in-group identification, religious group membership, and intergroup conflict in moderating in-group and out-group affect, Cairns et al. (2006) find that those who identify highly with their religious in-group display more in-group bias and stronger out-group negativity.

In the Turkish setting, the Sunni version of Islam has enjoyed a privileged position in Turkish society and polity. ${ }^{2}$ Promoting and upholding Sunni Islam, the Turkish state has rejected official recognition of the Alevi minority, known as a heterodox, syncretistic Muslim community. Rather, Alevis have been discriminated against and suppressed in social and political domains in Turkey. ${ }^{3}$ As a result, Alevis have remained socially, politically, and economically marginalized and peripheral (see Shankland, 2003; Erdemir, 2005; Poyraz, 2005; Çelik, Bilali and Iqbal, 2017). For instance, in the 1960s and 1970s in particular, Alevis were treated as one of the three major threats to the Turkish state, together with Communists and Kurdish nationalists (Erdemir, 2005). Moreover, the Turkish state has promoted Sunni Islamic understandings through the Directorate of Religious Affairs (Diyanet) as well as through public education. It is well known that the compulsory religious courses introduced in the early 1980s are based on Sunni beliefs and practices. In addition to social and political marginalization, Alevis have also been the target of sporadic violence in urban centres, such as in the Maraş (1978) and Sivas (1993) massacres. Finally, given certain differences between Alevi and Sunni religious teachings and practices (e.g. Alevis pray in cemevi, while Sunnis attend mosques; Alevis fast during Muharram month, while Sunnis in Ramadan; also Alevis attribute much more importance to Ali, cousin, and son-in-law of prophet Muhammad), many Sunnis do not really consider Alevis as true Muslims. Hence, the Alevi minority constitutes a religious out-group for a substantial number of Sunnis. Hence, one might expect that:

H2: Relatively more-religious Sunni-Turks are socially more distant to Alevis.
Regarding the role of religiosity in Sunni-Turks' attitudes towards the largest ethnic out-group (i.e. Kurds), it is an empirical fact that Islam in the Turkish social landscape is not a main boundary marker among ethnic groups because the vast majority of Turks and Kurds self-identify as Sunni-Muslim. In other words, being Muslim constitutes a religious superordinate identity or category among Turks and Kurds. One might expect that among more-religious individuals, the notion of an Islamic brotherhood would be stronger. A strong attachment to a shared, overarching Muslim identity might, in return, promote more tolerant attitudes between Muslim ethnic in-group and out-group members. For instance, Hindriks, Coenders and Verkuyten (2014: p. 56) hypothesize that "when individuals identify more strongly with their religious group, they can be expected to regard those who have the same faith more strongly as in-group members'. Indeed, in their analysis of interethnic minority relations among immigrant groups in The Netherlands, the authors find confirming evidence for the claim that more-religious Muslims are more positive towards Muslim out-groups (i.e. Turkish and Moroccan immigrants). Hence, in the Turkish context, relatively more-religious Sunni-Turks should be more likely to have a positive attitude towards coreligionists (i.e. Muslim ethnic out-groups such as Kurds). Thus, one might postulate that:

H3: Relatively more-religious Sunni-Turks should be socially less distant to Kurds, most of whom are SunniMuslim.

Nationalism: Another main explanatory variable for a majority group's negative attitudes towards ethnic and religious minority groups is (ethno)nationalist orientations. With competing or conflicting ethnic or national groups, one might expect ethnocentric orientations or in-group favouritism and out-group derogation or negativity to be more potent among in-group members with stronger attachments and loyalties to a given ethnic or national group (i.e. high identifiers).

In addition to promoting positive in-group evaluations, strong national in-group identification and loyalty (i.e. feelings of national in-group superiority and dominance) are likely to increase prejudice and intolerance towards members of competing ethnic or national outgroups (see also Cairns et al., 2006; Verkuyten and Yildiz, 2006; Çelebi, Verkuyten and Smyrnioti, 2016; Taşdemir and Öner-Özkan, 2016). In other words, under conflictual circumstances, a positive evaluation of one's national or ethnic group might be related to a derogation of other national or ethnic groups. For instance, 
Verkuyten and Yildiz (2006) provide evidence that increases in Turks' ethnic identification reduce their support for Kurdish minority rights. Similarly, Çelebi, Verkuyten and Smyrnioti (2016: p. 1037) expect that 'those individuals with high in-group identification are more worried about the status and position of their ingroup than [those with] lower identifiers. This is particularly the case when the value of the group identity is threatened and group interests are at risk'. The authors' empirical findings support such an expectation: strong national and ethnic identification among Turks decrease support for Kurdish language rights. In the context of Northern Ireland, Cairns et al. (2006) show that ingroup bias is stronger for high in-group identifiers than it is for low in-group identifiers. In their research on the nexus between national identification and out-group rejection in the German and British contexts, Mummendey, Klink and Brown (2001) show that in intergroup comparison conditions, national identification, and positive in-group evaluation are linked to outgroup rejection or derogation.

In the Turkish context, citizenship and the official understanding of national identity have been based on Turkishness. As is widely known, the Turkish Republic was established in the early 1920 s as a centralized nation-state based on strong Turkish nationalism. The newly established state imposed Turkishness as an overarching identity on society, despite several other ethnic, linguistic, and cultural groups residing in the country. Expecting every individual to identify herself or himself as a Turk, the state pursued assimilationist and/or repressive policies towards other ethnic and cultural identities in the public sphere (e.g. Kurdish identity and culture) (Kirişçi and Winrow, 1997; Yeğen, 2004, 2009). Therefore, the majority of ethnic group (i.e. Turks) has enjoyed a privileged status in social and political domains in the Republican period.

Furthermore, since the early 1980s, the Kurdish ethnopolitical movement in both peaceful and violent forms has posed a major challenge to the Turkish state and the official understanding of national identity, which has been based on Turkishness (see Kirişçi and Winrow, 1997; Bruinessen, 2000; Yeğen, 2004, 2009; Marcus, 2007; Watts, 2010; Gunes, 2012; Romano and Gurses, 2014; Aydin and Emrence, 2015; Sarigil and Karakoc, 2016). As the dominant or hegemonic group, SunniTurks might consider the Kurdish challenge a major threat to their dominant status in the public realm and so develop a relatively stronger negative attitude towards the Kurdish ethnic out-group. In other words, Kurdish deviation from and challenge to the superordinate identity (i.e. Turkishness), as well as Kurdish demands for cultural and political rights, are likely to empower a perceived threat among Sunni-Turks and so promote their social closure and distance towards the Kurdish ethnic minority (see also Çelebi, Verkuyten and Smyrnioti, 2016; Taşdemir and Öner-Özkan, 2016). ${ }^{4}$

Given the above factors, more-nationalist members of the dominant group (i.e. Turks) would likely be more concerned with Turkish national identity and interests, such as the unity and survival of the Turkish state, than less-nationalist members would. As a result, nationalist members of the Turkish in-group would likely consider the Kurdish ethnic identity and Kurdish demands for cultural and political rights (e.g. official recognition of the Kurdish language and ethnic identity and power sharing arrangements such as regional autonomy) as major threats to national and state interests. In addition, as the existing research also indicates, members of the dominant group may reject minority rights and demands because they are perceived as a threat to the dominant group's culture, identity, and privileges (see Scheepers, Gijsberts and Coenders, 2002; Verkuyten and Yildiz, 2006). In the context of competitive intergroup relations and interactions, all these dynamics would generate stronger out-group derogation and antagonistic attitudes among nationalist in-group members towards ethnic out-groups. Thus, one might postulate that:

\section{H4: Relatively more-nationalist Sunni-Turks are socially more distant to Kurds.}

Regarding the impact of nationalist orientations of the Turkish majority on their attitudes towards the Alevi religious minority, as discussed above, Alevi identity constitutes the 'Other' of religious members of the Sunni majority in Turkey (see also Çelik, Bilali and Iqbal, 2017). However, since the majority of Alevis in Turkey are of Turkish origin, one might expect that nationalist orientations among Turks should not cultivate a negative attitude towards members of the Alevi minority. In other words, the shared ethnicity between the Turkish majority and the Alevi minority should prevent or at least dampen any negative attitude among nationalist members of Turks towards Alevis. Thus, another hypothesis to test is as follows:

H5: Nationalist orientations among Turks should not have impact on their social distance from Alevis.

\section{Data, Variables, and Measurement}

To investigate the determining factors of ethnic and religious prejudices in the Turkish setting and to test the hypotheses presented above, I employ original data 
provided by a new public opinion survey. As part of a broader research project on Turkish public opinion, a nationally representative survey was conducted in April 2015. Professional interviewers of a public-opinion research company, based in Istanbul, carried out the fieldwork. The survey involved face-to-face interviews with 7,099 adult participants (18 years and older) from 12 NUTS-1 statistical regions, 50 provinces, 174 districts (ilçe), and 398 neighbourhoods (mahalle) and villages. Respondents were selected using a multi-stage, stratified, clustered random sampling procedure. Once households were selected randomly, age and gender quotas were applied in selecting one respondent from each household. ${ }^{5}$ The survey included questions about the attitudes towards the largest religious and ethnic minorities, and this study utilizes participants' responses to those questions to measure Sunni-Turks' ethnic and religious social closures and prejudices (see below).

As this study examines members of the majority group's (i.e. Sunni-Turks) attitude towards Turkey's largest ethnic and religious minorities (i.e. Kurds and Alevis, respectively), the statistical analyses below were conducted with data provided by a Sunni-Turkish subsample $(4,745$ participants, corresponding to 67 per cent of the overall sample). To measure participants' religious and ethnic origins, the survey included questions about ethnic and religious backgrounds. In other words, I relied on individuals' self-identification to measure ethnic and religious origins.

\section{Dependent Variable}

Intergroup prejudice constitutes the dependent variable in the statistical analyses. Regarding the measurement of the dependent variable, prejudice by definition involves creating distance from and exclusiveness towards outgroup members. Naturally, strong prejudice vis-à-vis a particular out-group implies a higher degree of social distance from that particular group. As Allport (1979: p.14) also notes, prejudice 'leads the individual to avoid members of the disliked group, even perhaps at the cost of considerable inconvenience'. Hence, I use professed attitudes towards intergroup social distance as a proxy for prejudicial attitudes towards out-group members, the main variable of interest in this study.

The concept of social distance, first coined by Bogardus (1925), simply refers to whether individuals from one social category (e.g. ethnicity, religion or class) are open to associating with those from another social category (see also Smith, McPherson and Smith-Lovin, 2014). Similarly, Alba and Nee (2003) suggest that social distance refers to a subjective feeling of nearness or closeness to certain individuals or groups. In terms of measuring social distance, Borgardus (1925) constructs a social distance scale by using individuals' responses to questions about their desire to engage in social contact of different degrees of closeness with out-group members, such as marriage, friendship, and neighbourliness (see also Qian and Lichter, 2007; Fox and Guglielmo, 2012; Çelik, Bilali and Iqbal, 2017). Following a similar strategy, I use individuals' attitudes towards having a neighbour, tenant, business partner, and son/daughterin-law from ethnic and religious minority out-groups to capture Sunni-Turks' social distance comfort with Kurds and Alevis.

Expecting that the determining factors of social distance are likely to differ across the public and private spheres, I analyse the category of son/daughter-in-law separately. Statistical analyses of the responses to the remaining three survey items (i.e. attitudes towards having a neighbour, tenant, and business partner from ethnic and religious minority out-groups) indicate that they are strongly related. The test for scale reliability generated high scores, indicating high internal consistency (Cronbach's alphas are 0.84 and 0.83 , respectively). In addition, principal component analyses reveal that these three items have high factor loadings on one single dimension, which I label social distance in the public realm. Thus, using those three items (i.e. attitude towards a neighbour, tenant, and business partner from an out-group), I constructed an additive index of the social distance of Sunni-Turks from each out-group in the public realm. This variable ranges from 0 to 3 , a higher score indicating a stronger degree of social closure and distance from the relevant out-group. Attitude towards son/daughter-in-law from an out-group is used as an indicator of social distance in the private realm. This is a binary variable, which ranges from 0 to 1 .

\section{Independent Variables}

As stated above, ideology, religiosity, and nationalism constitute our three main independent variables. In measuring ideological orientations, I rely on respondents' self-placement on a left-right continuum. The ideology variable ranges from 1 (strong leftist orientation) to 5 (strong rightist orientation).

Regarding the measurement of religiosity, existing empirical research treats religiosity as a complex concept with multiple dimensions such as belief, practice/worship, and attitude (Carkoglu and Kalaycioglu, 2009; Yeşilada and Noordijk, 2010; Phalet et al., 2013). As a result, multiple religion-related items were included in the questionnaire. Using those survey items, I conducted 
principal component analyses, which helped identify two dimensions of religiosity: faith and attitude/practice. Since almost all survey participants expressed a belief in God and an afterlife, the faith index, which had almost no variance, was excluded from the models. The remaining attitude/practice index is composed of the following six items: daily praying (five times), fasting during Ramadan month, support for wearing headscarves for primary students and public employees, support for Sharia law, and opposition to financial interest. This variable is an ordinal variable, ranging from 0 to 6 . High values represent stronger religiosity.

With respect to nationalism, due to a lack of better indicators, this study utilized support for the ultranationalist Nationalist Action Party (Milliyetçi Hareket Partisi, MHP) as an indicator of Sunni-Turks' nationalist orientations. Although using support for the MHP to measure nationalist orientations might be considered a limited measurement strategy, Sunni-Turk voting for the MHP, a party that articulates and mobilizes strong Turkish nationalist sentiments in society and politics, would be a useful proxy for the strength of (ethno)nationalist identifications and orientations of the members of majority group. This indicator would be quite useful at least in terms of identifying those who have strong attachments and loyalties to the Turkish nation and nationalism (i.e. high identifiers). This variable ranges from 0 (vote for other parties) to 1 (vote for the nationalist $\mathrm{MHP}$ ).

Since religion and nationalism can become entangled or intertwined (see Brubaker 2012; White 2014), one might expect that the interaction between religiosity and nationalism might also mould intergroup social distance and prejudice. In other words, the effect of religiosity on social distance from ethnic and religious out-group members might be different across nationalist and nonnationalist individuals. Thus, taking that possibility into account, I added an interaction term to the models to capture the possible impact of the interaction between religiosity and nationalism on out-group rejection.

\section{Control Variables}

The existing research suggests that individuals' demographic and socio-economic characteristics (e.g. education, income, social class, and gender) are also likely to influence intergroup social distance and prejudice. For instance, studying core discussion networks among Turkish and Moroccan immigrants in The Netherlands, van Tubergen (2015) finds that as the socio-economic status of these groups increases, the likelihood of having a Dutch confidant increases. In other words, a higher socio-economic status tends to weaken Turks and Moroccans' social closure towards individuals of Dutch origin. Similarly, in their research on opposition among European citizens to granting civil rights to legal migrants, Scheepers, Gijsberts and Coenders (2002) show that ethnic closure and exclusionism are stronger among less-educated and lower-income groups, as well as among manual workers and unemployed people. Hence, in this study, I also take into account the role of in-group members' basic demographic and socioeconomic circumstances and so control for factors and variables such as income (household income), employment, education (highest obtained level of education), age, gender, and area of residence (rural-urban). In measuring the controlled variables, I use corresponding questions in the survey (for descriptive statistics of all variables, see Table 1$)$.

\section{Results}

To begin with descriptive findings, Figure 1 indicates that as we move from a social relationship that involves a relatively lower level of interaction and intimacy with out-group members (e.g. being a neighbour) to a social relationship that requires a higher level of interaction and intimacy (e.g. family member), Sunni-Turks' negative attitudes towards ethnic and religious out-groups increase. As a result, Sunni-Turks' opposition to having a family member (i.e. son/daughter-in-law) from those out-groups is the highest of the relationships, and their opposition to an out-group neighbour is the lowest. This finding suggests that compared to the public realm, Sunni-Turks' ethnic and religious social closure is relatively stronger in the private domain. In other words, Sunni-Turks are socially more distant towards ethnic and religious minority groups in the private domain, which implies that ethnic and religious social boundaries appear to be relatively thicker, brighter, and so less porous or permeable in the private sphere. This finding is to be expected because 'preferences to establish and maintain ties with similar others are stronger when it comes to more intimate, expressive and long-term relations compared to more superficial, instrumental and shortterm relations' (van Tubergen, 2015: p. 106).

A striking finding, however, is that in the public sphere, a negative attitude towards ethnic out-group members is stronger than a negative stance towards religious out-group members. The descriptive statistics presented in Table 1 also confirm that Sunni-Turks' average social distance from Kurds in the public realm is relatively higher than their average distance from Alevis $(t=8.0615, d f=4667, P$-value $=9.493 \mathrm{e}-16)$. This 
Table 1. Descriptive statistics of variables

\begin{tabular}{|c|c|c|c|c|c|}
\hline Variables & $N$ & Mean & Standard deviation & Minimum & Maximum \\
\hline \multicolumn{6}{|l|}{ Dependent } \\
\hline Index of social distance from Kurds (public realm) & 4,730 & 0.99 & 1.206 & 0 & 3 \\
\hline Social distance from Kurds (private realm) & 4,722 & 0.50 & 0.500 & 0 & 1 \\
\hline Index of social distance from Alevis (public realm) & 4,680 & 0.85 & 1.144 & 0 & 3 \\
\hline Social distance from Alevis (private realm) & 4,678 & 0.56 & 0.496 & 0 & 1 \\
\hline \multicolumn{6}{|l|}{ Independent } \\
\hline Ideology (left-right) & 4,708 & 3.36 & 0.918 & 1 & 5 \\
\hline Religiosity (index) & 4,706 & 3.64 & 1.816 & 0 & 6 \\
\hline Nationalism & 4,727 & 0.18 & 0.381 & 0 & 1 \\
\hline$($ Religiosity $) *($ Nationalism $)$ & 4,726 & 0.63 & 1.537 & 0 & 6 \\
\hline \multicolumn{6}{|l|}{ Control Variables } \\
\hline Gender (0: female; 1 : male) & 4,745 & 0.49 & 0.500 & 0 & 1 \\
\hline Age & 4,745 & 39.59 & 13.706 & 18 & 97 \\
\hline Education & 4,716 & 4.39 & 1.229 & 1 & 7 \\
\hline Unemployment & 4,728 & 0.05 & 0.228 & 0 & 1 \\
\hline Household income group & 4,588 & 2.54 & 1.314 & 1 & 10 \\
\hline Residential area (0: rural; 1 : urban) & 4,745 & 0.66 & 0.474 & 0 & 1 \\
\hline
\end{tabular}

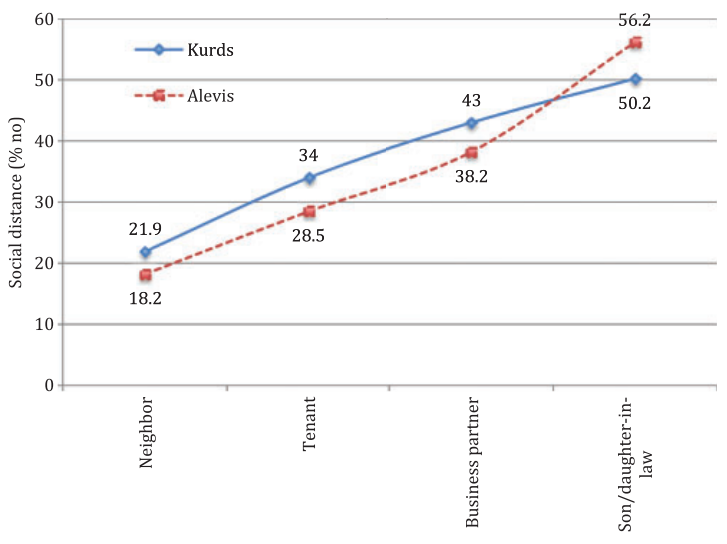

Figure 1. Sunni-Turkish majority's social distance to Kurds and Alevis

finding implies that the dominant group's ethnic closure appears to be relatively stronger than its religious closure in the public sphere. In other words, in the public domain, ethnic prejudice appears to be relatively more powerful than religious prejudice, which implies the presence of relatively brighter ethnic boundaries. This result might be one of the consequences of the three decades of bloody Kurdish conflict in Turkey.

Finally, while around half of Sunni-Turks would reject having a family member (i.e. son/daughter-in-law) from an ethnic out-group (Kurds), a majority of SunniTurks (56 per cent) would disapprove of a family member from a religious out-group (Alevis), suggesting that the members of the majority group appear to be socially more distant from the Alevi out-group in the private sphere $(t=-7.0675, d f=4659, P$-value $=1.812 \mathrm{e}-12)$. This finding indicates that in the private domain, SunniTurks' religious closure appears to be relatively stronger than their ethnic closure. To put it differently, in the private domain, the dominant group's attitude towards the religious out-group is relatively more exclusionary and prejudicial than its attitude towards the ethnic outgroup.

Overall, Figure 1 indicates the presence of a substantial degree of prejudice and intolerance of Sunni-Turks towards religious and ethnic minorities, which constitutes a serious problem for social integration and harmony in the Turkish context (see also Çarkoğlu and Toprak, 2007). Furthermore, it is striking that ethnic homophily is the dominant tendency in the public sphere, while it is religious homophily in the private space. Given these intriguing findings, we should raise the following question: How can we explain the variance in Sunni-Turks' social closure and distance towards the largest ethnic and religious minority groups in the public and private social arenas? The following section provides multivariate models of Sunni-Turks' exclusionary and prejudicial attitudes towards Kurds and Alevis.

\section{Multivariate Analyses}

Table 2 presents the results of logistic regression analyses around Sunni-Turks' social distance from Kurds. Before specifying and estimating the models, I conducted some multicollinearity tests to see if there were any strong associations among the ideology, religiosity, and 
Table 2. Logistic regression analysis of Sunni-Turks' social distance from Kurds

\begin{tabular}{|c|c|c|c|c|c|c|}
\hline \multirow[t]{2}{*}{ Predictors } & \multicolumn{3}{|c|}{ Public realm ${ }^{a}$} & \multicolumn{3}{|c|}{ Private realm ${ }^{\mathrm{b}}$} \\
\hline & Model 1a & Model 1b & Model 1c & Model 2a & Model 2b & Model 2c \\
\hline Ideology & $\begin{array}{r}0.191 * * * \\
(0.032)\end{array}$ & & & $\begin{array}{r}0.228 * * * \\
(0.033)\end{array}$ & & \\
\hline Religiosity & & $\begin{array}{c}-0.087 * * * \\
(0.016)\end{array}$ & $\begin{array}{c}-0.102 * * * \\
(0.018)\end{array}$ & & $\begin{array}{c}-0.087 * * * \\
(0.017)\end{array}$ & $\begin{array}{c}-0.087 * * * \\
(0.019)\end{array}$ \\
\hline Nationalism & & $\begin{array}{r}0.928 * * * \\
(0.072)\end{array}$ & $\begin{array}{r}0.648 * * * \\
(0.160)\end{array}$ & & $\begin{array}{r}0.856^{* * * *} \\
(0.084)\end{array}$ & $\begin{array}{r}0.863 * * * \\
\quad(0.202)\end{array}$ \\
\hline$($ Religiosity $) *($ Nationalism $)$ & & & $\begin{array}{l}0.080 \% \\
\quad(0.041)\end{array}$ & & & $\begin{array}{l}-0.002 \\
\quad(0.050)\end{array}$ \\
\hline Gender & $\begin{array}{r}-0.016 \\
(0.058)\end{array}$ & $\begin{array}{r}-0.057 \\
(0.058)\end{array}$ & $\begin{array}{l}-0.060 \\
\quad(0.058)\end{array}$ & $\begin{array}{r}-0.056 \\
(0.061)\end{array}$ & $\begin{array}{r}-0.073 \\
(0.062)\end{array}$ & $\begin{array}{c}-0.073 \\
\quad(0.062)\end{array}$ \\
\hline Age & $\begin{array}{l}-0.002 \\
(0.002)\end{array}$ & $\begin{array}{r}-0.0006 \\
(0.002)\end{array}$ & $\begin{array}{r}-0.0008 \\
(0.002)\end{array}$ & $\begin{array}{r}-0.0007 \\
(0.003)\end{array}$ & $\begin{array}{l}0.0004 \\
\quad(0.003)\end{array}$ & $\begin{array}{l}0.0004 \\
\quad(0.003)\end{array}$ \\
\hline Education & $\begin{array}{l}0.069 * \\
\quad(0.028)\end{array}$ & $\begin{array}{l}0.014 \\
\quad(0.029)\end{array}$ & $\begin{array}{l}0.011 \\
\quad(0.029)\end{array}$ & $\begin{array}{r}0.114 * * * \\
(0.030)\end{array}$ & $\begin{array}{l}0.063 * \\
\quad(0.031)\end{array}$ & $\begin{array}{l}0.063 * \\
\quad(0.031)\end{array}$ \\
\hline Unemployment & $\begin{array}{l}0.036 \\
\quad(0.127)\end{array}$ & $\begin{array}{l}0.085 \\
\quad(0.128)\end{array}$ & $\begin{array}{l}0.085 \\
\quad(0.127)\end{array}$ & $\begin{array}{l}0.116 \\
\quad(0.138)\end{array}$ & $\begin{array}{l}0.173 \\
\quad(0.139)\end{array}$ & $\begin{array}{l}0.173 \\
\quad(0.139)\end{array}$ \\
\hline Income & $\begin{array}{l}-0.028 \\
\quad(0.024)\end{array}$ & $\begin{array}{l}-0.025 \\
\quad(0.025)\end{array}$ & $\begin{array}{l}-0.025 \\
\quad(0.025)\end{array}$ & $\begin{array}{l}-0.029 \\
\quad(0.025)\end{array}$ & $\begin{array}{c}-0.031 \\
(0.026)\end{array}$ & $\begin{array}{c}-0.031 \\
\quad(0.026)\end{array}$ \\
\hline Residential area & $\begin{array}{c}-0.284 * * \\
(0.062)\end{array}$ & $\begin{array}{c}-0.263 * * * \\
(0.063)\end{array}$ & $\begin{array}{c}-0.271 * * * \\
(0.063)\end{array}$ & $\begin{array}{c}-0.405 * * \\
(0.067)\end{array}$ & $\begin{array}{c}-0.408 * * * \\
(0.067)\end{array}$ & $\begin{array}{c}-0.408 * * * \\
(0.067)\end{array}$ \\
\hline Log likelihood & $\begin{array}{c}-5,325.904 \\
(d f=10)\end{array}$ & $\begin{array}{c}-5,222.056 \\
(d f=11)\end{array}$ & $\begin{array}{c}-5,220.153 \\
(d f=12)\end{array}$ & $\begin{array}{c}-3,068.912 \\
(d f=8)\end{array}$ & $\begin{array}{c}-3,013.902 \\
(d f=9)\end{array}$ & $\begin{array}{c}-3,013.902 \\
(d f=10)\end{array}$ \\
\hline Akaike Information Criterion (AIC) & $10,671.81$ & $10,466.11$ & $10,464.31$ & $6,153.8$ & $6,045.8$ & $6,047.8$ \\
\hline$N$ & 4,510 & 4,492 & 4,492 & 4,503 & 4,486 & 4,486 \\
\hline
\end{tabular}

Notes: $* P<0.05, * P<0.01, * * * P<0.001$.

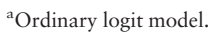

${ }^{\mathrm{b}}$ Binary logit model.

Standard errors are in parentheses.

nationalism variables. The results indicate that there is not really a multicollinearity between religiosity and nationalism; however, there is some degree of multicollinearity among the ideology and religiosity and nationalism variables. Thus, I decided to estimate the effect of the ideology variable separately. The multivariate analyses confirm almost all of the hypothetical expectations presented above. To begin with the impact of the ideology variable, the results suggest that the political orientations of Sunni-Turks matter in terms of out-group rejection and hostility: compared to left-oriented Sunni-Turks, right-oriented Sunni-Turks have a moreexclusionary attitude towards the Kurdish ethnic minority in both the public and private spheres. This result is probably because the Kurdish ethnonationalist movement in Turkey has been presenting itself as a leftist movement, and it appears that such a political stance boosts right-oriented Sunni-Turks' exclusionary attitudes towards Kurds. This interesting finding implies that ideological and political orientations might play a substantial role in intergroup relations in the social domain. In other words, ideological cleavages matter not only in the political domain but also in the social sphere (see below as well).

Regarding the impact of religiosity on Sunni-Turks' social distance from the ethnic minority, as religiosity increases, social distance from Kurds in both the public and private realms decreases, and this relationship holds across various model specifications. In other words, more-religious Sunni-Turks have a relatively more positive attitude towards Kurds, who constitute the largest Muslim ethnic out-group in the Turkish social landscape. This finding provides supporting evidence for the Muslim-brotherhood argument. As stated above, being Sunni-Muslim constitutes a shared, superordinate identity among Turks and Kurds. A superordinate SunniMuslim identity appears to cultivate a positive attitude among relatively more-religious members of the 
majority group towards other Muslim ethnic groups. This finding, however, does not mean that the same relationship holds for members of the minority out-group. The existing research shows that religious members of the ethnic minority group (i.e. Kurds) do not have a more positive attitude towards the members of the Turkish majority (see Sarigil and Karakoc, 2017).

Regarding nationalism, as expected, increases in nationalist orientations augment social distance from Kurds across public and private spheres alike. In other words, nationalist members of the dominant group have stronger social closure and prejudice towards the ethnic minority out-group (see also Dixon and Ergin, 2010; Çelik, Bilali and Iqbal, 2017). This finding is in line with previous research, which suggests that in the case of competitive and conflictual situations, as in Turkish society, in-group identification 'fosters in-group solidarity and activism on behalf of one's group, and high identifiers tend to be more concerned about the continuity and rights of their group' (Çelebi, Verkuyten and Smyrnioti, 2016: p. 1037; see also Verkuyten and Yildiz, 2006; van Zomeren, Postmes and Spears, 2008). It appears that nationalist members of the dominant group (Sunni-Turks) consider the Kurdish ethnic identity and Kurdish demands for political and cultural rights as a major threat to their own group's identity and dominant status, as well as to national and state unity. This outlook, in return, breeds a negative stance among nationalist Sunni-Turks towards the Kurdish ethnic minority.

With respect to the impact of the interaction effect, the coefficient of the interaction term in Model $1 \mathrm{c}$ is positive and statistically significant, which indicates that the interaction between nationalism and religiosity appears to matter in terms of out-group rejection in the public sphere. In other words, the impact of religiosity is likely to be conditioned by nationalism. When we convert the coefficients (i.e. log odds or logits) into odds ratios, we see that among non-nationalist religious Sunni-Turks, a unit increase in religiosity reduces the odds of social distance from Kurds by 10 per cent. However, in the case of nationalist religious Sunni-Turks, a unit increase in religiosity reduces the odds of social distance from Kurds by 2 per cent. This finding suggests that nationalism appears to confine or limit the negative effect of religiosity on social distance from Kurds.

Interestingly, unlike political and cultural factors and divisions such as ideology, religiosity, and nationalism, socio-economic factors such as education, income level, and unemployment either do not matter or have limited impact on Sunni-Turkish majority's anti-Kurdish attitudes. This finding contrasts with the findings of
Scheepers, Gijsberts and Coenders (2002) and of van Tubergen (2015). This surprising result suggests that competition over material resources may not be the only source of ethnic threat perceptions. Rather, competition over political and cultural values and over norms and identity might also feed perceived ethnic threats and so breed prejudice and exclusionism towards competing ethnic out-groups (see also Schneider, 2008). Practically, this finding suggests that improvements in the socioeconomic status of Sunni-Turks may not necessarily contain or weaken their hostility or antagonism towards the Kurdish ethnic minority.

Finally, the type of residential area also matters. Among Sunni-Turks living in urban areas, we see a relatively lower degree of social distance from Kurds. This finding is probably because the likelihood of Sunni-Turks' interaction with members of the Kurdish out-group is higher in urban centres. Hence, a high degree of familiarity with the Kurdish out-group appears to reduce Sunni-Turks' prejudice and intolerance. This finding is in line with the famous social-contact hypothesis, which postulates that intergroup contact tends to limit prejudice towards out-group members and so limit hostility among social groups (see Allport, 1979; Brown, 1995; Pettigrew and Tropp, 2008; Schneider, 2008; Frølund Thomsen, 2012; Hindriks, Coenders and Verkuyten, 2014).

Moving to the dominant majority group's social closure towards the Alevi minority, Table 3 displays the results of logistic regression analyses of Sunni-Turks' social distance from Alevis. The ideology variable has a similar impact on the majority group's social distance from the religious out-group: compared to a leftoriented Sunni-Turk, a right-oriented Sunni-Turk has a stronger exclusionary attitude towards members of the Alevi out-group in the both public and private realms. This finding indicates that in addition to ethnic prejudice, religious prejudice is also stronger among rightoriented members of the dominant group. All these findings indicate that ideological and political orientations and divisions can be a major factor in both ethnic and religious social closure and boundary-making processes. In other words, the results confirm that political divisions and antagonisms can easily spill over into the social domain and trigger or empower out-group rejection and thus social tensions and conflicts.

Regarding religiosity, in line with the expectations, increases in religiosity empower Sunni-Turks' exclusionary and prejudicial attitudes towards Alevis in both the public and the private realms. In other words, more-religious members of the Sunni-Turkish majority are socially more distant to members of the religious out-group. This finding 


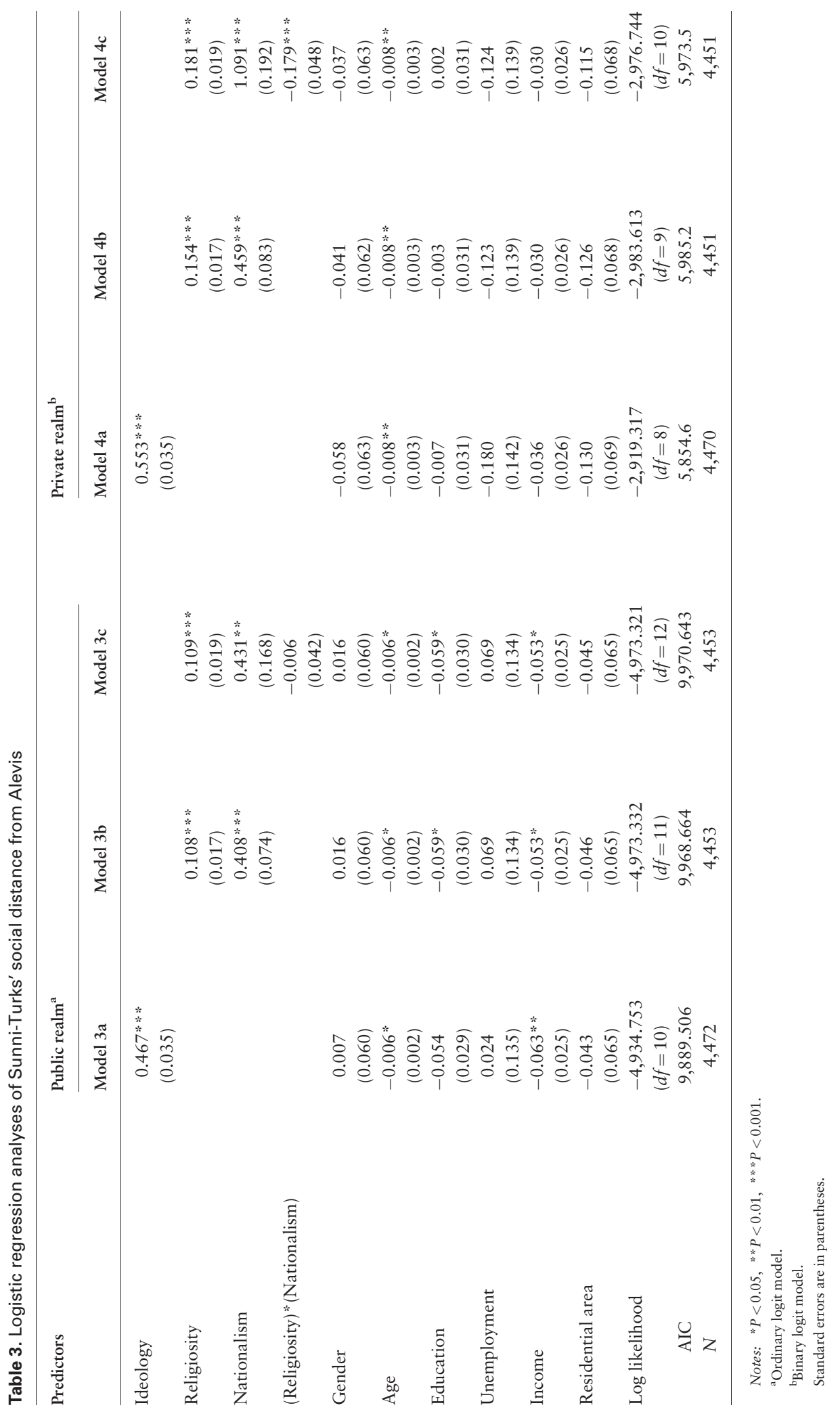


implies that more-religious Sunni-Turks tend to draw thicker social boundaries vis-à-vis the Alevi minority across the public and private spheres. This result is probably because, as discussed above, many religious SunniTurks view Alevis as almost non-Muslims or the religious 'Other', and so are less willing to develop relations with them.

Unlike the expectations, nationalism appears to empower negative and prejudicial attitudes towards Alevis. The statistical results in Table 3 indicate that stronger nationalist orientations among Sunni-Turks are associated with a higher degree of social distance from the religious minority in both the public and private domains. This striking finding indicates that relatively morenationalist members of the dominant group are socially more distant from not only the ethnic out-group but also from the religious out-group. In other words, ethnic and religious closures are both stronger among relatively morenationalist members of the dominant majority group.

In terms of the interaction effect, nationalism appears to condition the positive effect of religiosity on social distance from Alevis in the private realm. For non-nationalist religious Sunni-Turks, a 1-unit increase in religiosity increases the odds of social distance from Alevis by 20 per cent, but among nationalist religious Sunni-Turks, it increases the odds of social distance from Alevis by 0.3 per cent. This finding shows that the interaction effect operates uniformly across attitudes towards ethnic and religious out-groups. In both cases, nationalism suppresses the impact of religiosity. However, in the Kurdish case it weakens the negative impact of religiosity on anti-Kurdish attitudes, and in the Alevi case it weakens the positive impact of religiosity on antiAlevi attitudes. Thus, nationalism conditions the impact of religiosity in favour of Alevis but not in favour of Kurds. This difference suggests that nationalist members of Sunni-Turks perceive the ethnic out-group (i.e. Kurds) as much more threatening than the religious outgroup (i.e. Alevis). Again, this situation should be interpreted as a result of the protracted and violent Kurdish conflict in the Turkish setting since the early 1980s.

Regarding the control variables, one notable finding is that more-senior Sunni-Turks appear to be socially less distant to the Alevi minority across public and private spaces. However, similar to the Kurdish case, socioeconomic factors either do not matter or have an inconsistent impact on Sunni-Turks' social distance to Alevis.

\section{Predicted Probabilities}

To have a better sense of the substantive impact of the variables of interest (i.e. ideology, religiosity, and nationalism) on exclusionary and prejudicial attitudes towards ethnic and religious minorities, I calculated the predicted probabilities of social distance from Kurds and Alevis in the private realm based on Models 2a and $2 c$, and $4 a$ and $4 c$, respectively. Regarding the effect of ideology, Figure $2 \mathrm{a}$ and $\mathrm{b}$ shows that moving from $\mathrm{a}$ leftist Sunni-Turk to a rightist Sunni-Turk increases the predicted probability of distance from Kurds by 22 per cent and from Alevis by 50 per cent, holding other independent variables at their mean values. These findings also confirm that ideological orientations in the political realm might be highly consequential for intergroup relations and attitudes in the social realm. In other words, political cleavages might spill over into social realm and substantially affect intergroup relations and dynamics.

With respect to the effect of religiosity, Figure $3 a$ and $b$ confirms that religiosity has a contrasting impact on social distance from Kurds and Alevis. Moving from the lowest to the highest level of religiosity decreases the probability of social distance from Kurds by 13 per cent and increases the probability of social distance from Alevis
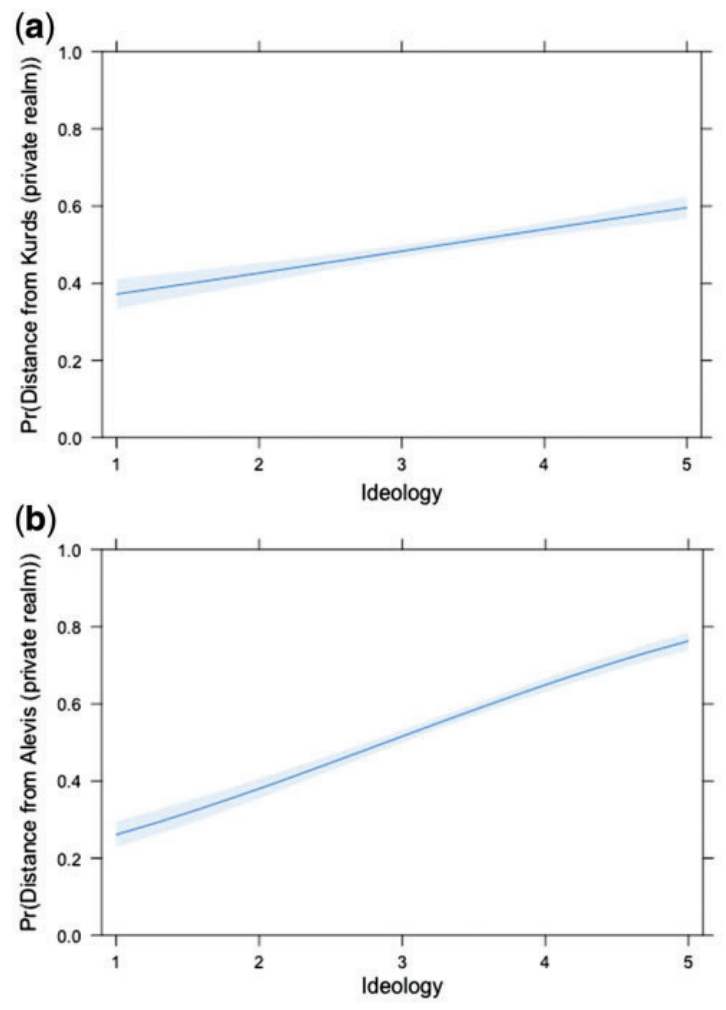

Figure 2. The effect of ideology on social distance from Kurds and Alevis in the private realm (predicted probabilities) 

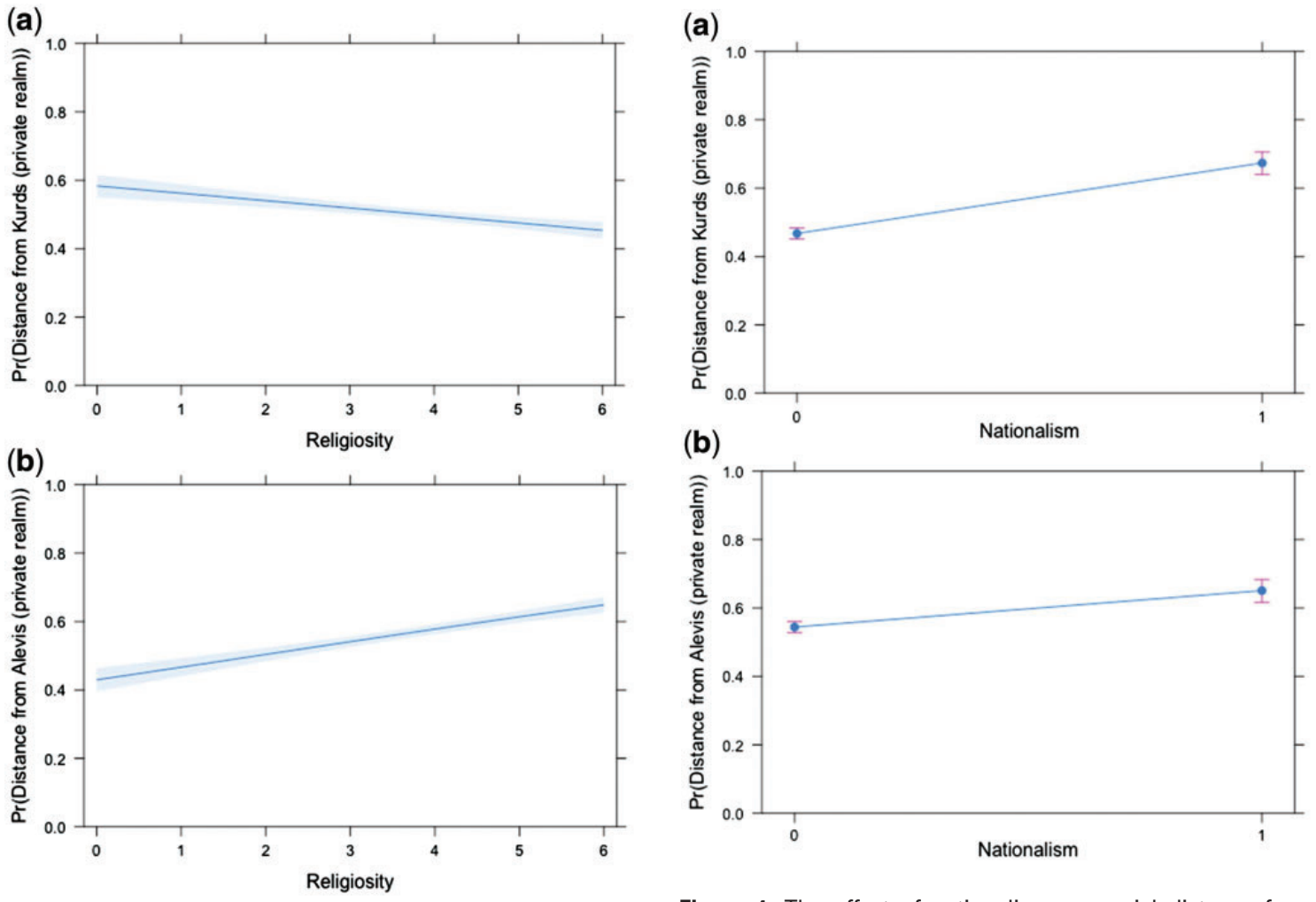

Figure 3. The effect of religiosity on social distance from Kurds and Alevis in the private realm (predicted probabilities)

by 22 per cent, holding other independent variables at their mean values.

Finally, with respect to the effect of nationalism, Figure $4 \mathrm{a}$ and $\mathrm{b}$ indicates that nationalism has a similar impact on social distance from ethnic and religious minority out-groups. Moving from a non-nationalist Sunni-Turk to a nationalist Sunni-Turk increases the probability of social distance from both Kurds and Alevis in the private domain (by 21 and 11 per cent, respectively). In other words, relatively more-nationalist members of the Sunni-Turkish majority have a higher degree of social closure vis-à-vis the ethnic and religious out-groups alike. Nationalist Sunni-Turks' relatively stronger out-group rejection implies that the former tend to contract ethnic and religious boundaries in the private realm.

\section{Implications}

Utilizing social identity and ethnic competition theories, as well as original survey data, this study examines the dominant majority group's social closure and prejudice towards the largest ethnic and religious minority groups

Figure 4. The effect of nationalism on social distance from Kurds and Alevis in the private realm (predicted probabilities)

in Turkey, a Muslim-majority country. The current study, which provides a comparative analysis of ethnic and religious prejudices in the Turkish social landscape, has major theoretical and practical ramifications. To begin with the theoretical implications, ECT focuses on the role of competition over economic resources in intergroup tensions and conflicts, as summarized above. Having such a limited focus, the theory remains generally 'asocial'. The empirical findings of the current study, however, imply that competition over relatively more ideational or symbolic values, such as prestige, status, legitimacy, norms, and identity, might also aggravate ethnic threat perceptions and so breed prejudicial and antagonistic attitudes in interethnic relations (see also Schneider, 2008). Thus, ECT should not treat competition over ideational or symbolic values and resources as epiphenomenal. Rather, cultural and political cleavages and competitions might exert a substantial autonomous causal impact on exclusionary and prejudicial attitudes towards out-groups.

Another possible extension of ECT would be having greater room for the role of historical legacies and memories. In addition to being asocial, the theory's current 
versions appear to be largely 'ahistorical', in the sense that the legacy of past cultural and political competitions, conflicts, and enmities is ignored. This orientation constitutes a limitation. The Turkish case, for example, evidences that such historical factors are likely to endure and drive threat perceptions and so shape prejudicial and antagonistic attitudes and behaviours in intergroup relations in contemporary times.

Regarding the practical implications of this article, many conservative or pro-Islamic social and/or political movements and actors advocate promoting religion and religious values and norms in social and political realms. For instance, Recep Tayyip Erdoğan, the unchallenged leader of Turkey's conservative Justice and Development Party (Adalet ve Kalkınma Partisi, AKP), which has dominated Turkish politics since the early 2000s, has stated several times that the party's goal is to raise pious generations. ${ }^{6}$ Indeed, AKP governments have been trying to promote Sunni Islam in Turkish society through various channels, such as by increasing the number of religious schools (i.e. Imam and preacher schools) and adding more courses on religion to the curriculum of secular national education. However, such a policy appears to be a double-edged sword in Turkey. This study's empirical findings display that while promoting religiosity among the Sunni-Turkish majority might empower positive attitudes towards the Kurdish ethnic minority, it might also strengthen the Sunni-Turkish majority's negative and prejudicial stance towards other minority groups, such as the Alevi minority.

Similarly, since relatively more-nationalist members of the dominant majority group in Turkey have stronger antagonistic attitudes towards the ethnic and religious minority out-groups alike, promoting Turkish nationalism in the political and social domains is likely to generate implicit or explicit tensions between the Turkish majority and Kurdish and Alevi minority groups. Indeed, although we have not seen mass-scale communal violence between the Sunni-Turkish majority and minority groups, we have witnessed in the past decades increasing antiminority attitudes and discourses in the social and political realms, as well as a growing number of cases of sporadic violence against minority groups in urban settings (e.g. marking Alevi houses with crosses, and physical attacks on Kurdish seasonal workers, buildings of proKurdish parties and Kurdish businesses in Turkey's western and central Anatolian provinces). One recent and quite telling example is that a Turkish nationalist mob prevented the burial of the body of Aysel Tuğluk's mother in Ankara's Gölbaşı district in September 2017. A pro-Kurdish politician, Aysel Tuğluk, was a deputy cochair of the pro-Kurdish Peoples' Democratic Party
(Halkların Demokratik Partisi, HDP) and is on trial for terrorism charges. Tuğluk was allowed to attend her mother's funeral with special permissions and accompanied by gendarmerie units. To avoid a possible nationalist reaction, the funeral was conducted at night; however, during the burial process, a group of nationalist protesters gathered at the cemetery. Chanting highly racist slogans, the mob threatened that her mother's body would be dug up if interred at that cemetery. Tuğluk's family had to take the body from the grave and transfer it to Tunceli, her hometown. ${ }^{7}$

Although political elites' discourses and policies based on a conservative-nationalist worldview (i.e. TurkishIslamic understandings) might resonate well with SunniTurks, such policies and discourses are likely to enhance that dominant group's prejudice and intolerance towards ethnic and religious minority out-groups. As Figure 1 indicates, exclusionary and prejudicial attitudes towards minority groups have been quite powerful among members of Sunni-Turkish majority. Also, as the multivariate analyses presented above indicate, political divisions seem to have a substantial impact on out-group rejection and exclusionary attitudes in the social realm. In addition, polarization along ethnic (Turks vs. Kurds) and religious lines (secular vs. Islamic) has increased in Turkish politics in the past decades. Given these factors, political elites' exclusionary discourses and actions are highly likely to encourage the Sunni-Turkish masses to demarcate brighter, thicker, and more rigid social boundaries in their relations with ethnic and religious minority groups, which would likely then promote feelings of alienation and resentment among ethnic and religious minority groups towards the dominant group. In brief, political elites' exclusionary and antagonistic discourses and actions towards ethnic and religious minorities may sharpen the existing religious and ethnic divisions and tensions in the social realm.

\section{Notes}

1 The notion of social identity refers to 'that part of an individual's self-concept which derives from this knowledge of his membership in a social group (or groups) together with the value and emotional significance attached to that membership' (Tajfel, 1981: p. 255).

2 In terms of the demographic structure, Sunni-Turks also constitute the majority of Turkish society (corresponding to around $65-70$ per cent of the total Turkish population).

3 It is, however, important to acknowledge that at certain periods, the Turkish state has also been discriminatory towards Sunni-Muslim groups. For instance, 
banning wearing headscarves in public institutions and buildings such as schools was discriminatory and suppressive towards conservative Sunni-Muslim women (see Guveli, 2011).

4 In the European context, Scheepers, Gijsberts and Coenders (2002) also find that the perception of ethnic threat is the most important predictor of ethnic closure and exclusionism.

5 Regarding the gender quota, data provided by the Turkish Statistical Institute (TUIK) on gender distribution across the country were followed. Thus, national gender balance was maintained in the sample. With respect to the age quota, only individuals aged 18 years and older were included in the survey.

6 See for instance, 'Dindar gençlik yetiştireceğiz', Hürriyet, 2 February 2012, available at http://www. hurriyet.com.tr/dindar-genclik-yetistirecegiz-19825231 (accessed 6 November 2016).

7 See 'Mob attacks funeral of mother of jailed HDP deputy co-chair Tuğluk in Ankara', Hürriyet Daily News, 14 September 2017, at http://www.hurriyet dailynews.com/funeral-of-mother-of-jailed-deputyhdp-co-chair-tugluk-attacked-by-group-in-ankara. aspx?pageID $=517 \& \mathrm{nID}=117952 \&$ NewsCatID $=509$ (accessed 23 September 2017).

\section{Acknowledgements}

Earlier versions of this article were presented at the 75 th Annual Conference of the Midwest Political Science Association (MPSA), 6-9 April 2017, Chicago, IL, USA, and at the Empirical Studies in Political Analysis (ESPA) 2017 Workshop, 20-22 January 2017, Izmir, Turkey. For useful comments and suggestions on earlier drafts of this study, the author is grateful to Steven Brooke, Ekrem Karakoc, Gizem Arikan Sekercioglu, and three anonymous reviewers of the ESR.

\section{Funding}

This work was supported by the Economic Policy Research Foundation of Turkey (Türkiye Ekonomi Politikaları Araştırma Vakf, TEPAV).

\section{References}

Alba, R. and Nee, V. (2003). Remaking the American Mainstream: Assimilation and Contemporary Immigration. Cambridge, MA: Harvard University Press.

Allport, G. W. (1979). The Nature of Prejudice, 25th Anniversary edn. Reading, MA: Addison-Wesley Publishing Company.

Aydin, A. and Emrence, C. (2015). Zones of Rebellion: Kurdish Insurgents and the Turkish State. Ithaca, NY: Cornell University Press.
Bogardus, E. S. (1925). Measuring social distance. Journal of Applied Sociology, 9, 299-308.

Brewer, M. B. (1986). The role of ethnocentrism in intergroup conflict. In Worchel, S. and Austin, W. G. (Eds.), Psychology of Intergroup Relations. Chicago, IL: Nelson-Hall Publishers, pp. 88-102.

Brewer, M. B. (2001). Ingroup identification and intergroup conflict: when does ingroup love become outgroup hate? In Ashmore, R. D., Jussim, L., and Wilder, D. (Eds.), Social Identity, Intergroup Conflict, and Conflict Reduction. New York, NY: Oxford University Press, pp. 17-41.

Brown, R. (1995). Prejudice: Its Social Psychology. Oxford: Blackwell Publishers.

Brubaker, R. (2012). Religion and nationalism: four approaches. Nations and Nationalism, 18, 2-20.

Bruinessen, M. V. (2000). Kurdish Ethno-Nationalism versus Nation-Building States: Collected Articles. Istanbul: The Isis Press.

Cairns, E. et al. (2006). The role of in-group identification, religious group membership and intergroup conflict in moderating in-group and out-group affect. British Journal of Social Psychology, 45, 701-716.

Çarkoğlu, A. (2005). Political preferences of the Turkish electorate: reflections of an Alevi-Sunni cleavage. Turkish Studies, 6, 273-292.

Carkoglu, A. and Kalaycioglu, E. (2009). The Rising Tide of Conservatism in Turkey. New York, NY: Palgrave Macmillan.

Çarkoğlu, A. and Toprak, B. (2007). Religion, Society and Politics in a Changing Turkey. Istanbul: TESEV.

Çelebi, E., Verkuyten, M. and Smyrnioti, N. (2016). Support for Kurdish language rights in Turkey: the roles of ethnic group, group identifications, contact, and intergroup perceptions. Ethnic and Racial Studies, 39, 1034-1051.

Çelik, A. B., Bilali, R. and Iqbal, Y. (2017). Patterns of 'othering' in Turkey: a study of ethnic, ideological, and sectarian polarisation. South European Society and Politics, 22, 217-238.

Dahinden, J. and Zittoun, T. (2013). Religion in meaning making and boundary work: theoretical explorations. Integrative Psychological and Behavioral Science, 47, 185-206.

Dixon, J. C. and Ergin, M. (2010). Explaining anti-Kurdish beliefs in Turkey: group competition, identity, and globalization. Social Science Quarterly, 91, 1329-1348.

Erdemir, A. (2005). Tradition and modernity: alevis' ambiguous terms and Turkey's ambivalent subjects. Middle Eastern Studies, 41, 937-951.

Fox, C. and Guglielmo, T. A. (2012). Defining America's racial boundaries: blacks, Mexicans, and European immigrants, 1890-19451. American Journal of Sociology, 118, 327-379.

Frølund Thomsen, J. P. (2012). How does intergroup contact generate ethnic tolerance? The contact hypothesis in a Scandinavian context. Scandinavian Political Studies, 35, 159-178.

Gunes, C. (2012). The Kurdish National Movement in Turkey: From Protest to Resistance. New York, NY: Routledge. 
Guveli, A. (2011). Social and economic impact of the headscarf ban on women in Turkey. European Societies, 13, 171-189.

Hewstone, M., Rubin, M. and Willis, H. (2002). Intergroup bias. Annual Review of Psychology, 53, 575-604.

Hindriks, P., Coenders, M. and Verkuyten, M. (2014). Interethnic attitudes among minority groups: the role of identity, contact, and multiculturalism. Social Psychology Quarterly, 77, 54-74.

Hogg, M. A. (2006). Social identity theory. In Burke, P. J. (Ed.), Contemporary Social Psychological Theories. Stanford, CA: Stanford University Press, pp. 111-136

Kirişçi, K. and Winrow, G. M. (1997). The Kurdish Question and Turkey: An Example of a Trans-State Ethnic Conflict. Portland, OR: Frank Cass.

Marcus, A. (2007). Blood and Belief: The PKK and the Kurdish Fight for Independence. New York, NY: New York University Press.

Mummendey, A., Klink, A. and Brown, R. (2001). Nationalism and patriotism: national identification and out-group rejection. British Journal of Social Psychology, 40, 159-172.

Okamoto, D. G. (2003). Toward a theory of panethnicity: explaining Asian American collective action. American Sociological Review, 68, 811-842.

Olzak, S. (1992). The Dynamics of Ethnic Competition and Conflict. Stanford, CA: Stanford University Press.

Pettigrew, T. F. and Tropp, L. R. (2008). How does intergroup contact reduce prejudice? Meta-analytic tests of three mediators. European Journal of Social Psychology, 38, 922-934.

Phalet, K. et al. (2013). The making and unmaking of religious boundaries. Comparative Migration Studies, 1, 123-145.

Poyraz, B. (2005). The Turkish state and Alevis: changing parameters of an uneasy relationship. Middle Eastern Studies, 41, 503-516.

Qian, Z. and Lichter, D. T. (2007). Social boundaries and marital assimilation: interpreting trends in racial and ethnic intermarriage. American Sociological Review, 72, 68-94.

Romano, D. and Gurses, M. (Eds.). (2014). Conflict, Democratization, and the Kurds in the Middle East: Turkey, Iran, Iraq, and Syria. New York, NY: Palgrave Macmillan.

Sarigil, Z. and Karakoc, E. (2016). Who supports secession? The determinants of secessionist attitudes among Turkey's Kurds. Nations and Nationalism, 22, 325-346.

Sarigil, Z. and Karakoc, E. (2017). Inter-ethnic (in)tolerance between Turks and Kurds: implications for Turkish democratisation. South European Society and Politics, 22, 197-216.

Savelkoul, M. et al. (2011). Anti-Muslim attitudes in the Netherlands: tests of contradictory hypotheses derived from ethnic competition theory and intergroup contact theory. European Sociological Review, 27, 741-758.

Scheepers, P., Gijsberts, M. and Coenders, M. (2002). Ethnic exclusionism in European countries: public opposition to civil rights for legal migrants as a response to perceived ethnic threat. European Sociological Review, 18, 17-34.
Schneider, S. L. (2008). Anti-immigrant attitudes in Europe: outgroup size and perceived ethnic threat. European Sociological Review, 24, 53-67.

Shankland, D. (2003). The Alevis in Turkey: The Emergence of a Secular Islamic Tradition. New York, NY: Routledge.

Smith, J. A., McPherson, M. and Smith-Lovin, L. (2014). Social distance in the United States: Sex, race, religion, age, and education homophily among confidants, 1985 to 2004. American Sociological Review, 79, 432-456.

Sumner, W. G. (2002). Folkways: A Study of Mores, Manners, Customs and Morals. New York, NY: Dover Publications.

Tajfel, H. (1981). Human Groups and Social Categories: Studies in Social Psychology. Cambridge: Cambridge University Press.

Tajfel, H. (1982). Social psychology of intergroup relations. Annual Review of Psychology, 33, 1-39.

Tajfel, H. and Turner, J. C. (1986). The social identity theory of intergroup behavior. In Worchel, S. and Austin, W. G. (Eds.), Psychology of Intergroup Relations. Chicago: Nelson-Hall, pp. 7-24.

Taşdemir, N. and Öner-Özkan, B. (2016). Definitions of Turkish in-group boundaries: national participation and essentialism as predictors of inter-group attitudes in Turkey. Nations and Nationalism, 22, 143-164.

Trittler, S. (2017). Explaining differences in the salience of religion as a symbolic boundary of national belonging in Europe. European Sociological Review, 33, 708-720.

van Tubergen, F. (2015). Ethnic boundaries in core discussion networks: a multilevel social network study of Turks and Moroccans in the Netherlands. Journal of Ethnic and Migration Studies, 41, 101-116.

Verkuyten, M. and Yildiz, A. A. (2006). The endorsement of minority rights: the role of group position, national context, and ideological beliefs. Political Psychology, 27, 527-548.

Watts, N. F. (2010). Activists in Office: Kurdish Politics and Protest in Turkey. Seattle; London: University of Washington Press.

White, J. (2014). Muslim Nationalism and the New Turks. Princeton, NY: Princeton University Press.

Yeğen, M. (2004). Citizenship and ethnicity in Turkey. Middle Eastern Studies, 40, 51-66.

Yeğen, M. (2009). "Prospective-Turks" or "pseudo-citizens": Kurds in Turkey. The Middle East Journal, 63, 597-615.

Yeşilada, B. A. and Noordijk, P. (2010). Changing values in Turkey: religiosity and tolerance in comparative perspective. Turkish Studies, 11, 9-27.

Van Zomeren, M., Postmes, T. and Spears, R. (2008). Toward an integrative social identity model of collective action: a quantitative research synthesis of three socio-psychological perspectives. Psychological Bulletin, 134, 504-535.

Zeki Sarigil (PhD, University of Pittsburgh, 2007) is an Associate Professor of Political Science at Bilkent University (Ankara, Turkey). His research interests include ethnicity, ethnonationalism, social closure and 
boundary-making, civil-military relations, and institutional theory (e.g. institutional change, path dependence, and informal institutions). He has published articles in such journals as European Political Science Review, European Journal of International Relations,
Nations and Nationalism, Ethnic and Racial Studies, Armed Forces \& Society, and South European Society and Politics. He is the author of Ethnic Boundaries in Turkish Politics: The Secular Kurdish Movement and Islam (New York: New York University Press, 2018). 